\title{
The Negative Impact of Boko Haram Insurgency on Women and Children in Northern Nigeria: An Assessment
}

\author{
Mustapha Alhaji Ali ${ }^{1}$, Ummu Atiyah Ahmad Zakuan² \& Mohammad Zaki bin Ahmad ${ }^{2}$ \\ ${ }^{1}$ Department of Political Science and Administration. Yobe State University, Damaturu, Nigeria \\ ${ }^{2}$ Ghazali Shafie Graduate School of Government College of Law, Government and International Studies School \\ of International Studies (SOIS), University of Utara Malaysia, Malaysia \\ Correspondence: Mustapha Alhaji Ali, Department of Political Science and Administration. Yobe State \\ University, Damaturu, Nigeria \\ To cite this article: Alhaji Ali, M., Zakuan, U. A. A., \& Ahmad, M. Z. bin. (2018). The Negative Impact of \\ Boko Haram Insurgency on Women and Children in Northern Nigeria: An Assessment. American International \\ Journal of Social Science Research, 3(1), 27-33. Retrieved from
} http://www.cribfb.com/journal/index.php/aijssr/article/view/141

Received: September 10, $2018 \quad$ Accepted: September 15, $2018 \quad$ Online Published: September 24, 2018

\begin{abstract}
This paper studies the negative impacts of Boko Haram insurgency on women and children in northern Nigeria. Indeed, Boko Haram has affected the lives of the general populace in northern Nigeria, precisely women and children, by turning the women to widows and children to orphans, the negative events of the sect groups have continually coursing a serious damage to the lives and properties of the peoples in the northern region. The researcher used the Secondary source in acquiring the appropriate data. The study found that this set of individuals and their negative activities have affected the lives and properties of women and children. It is noted that many women have turned to widows and children to orphans. In view of this, the paper recommends that the government should intervein to provide the affected women and children with some empowerment programmes. It should also provide a good shelter to those that lost their husbands and residents, the government, traditional rulers, and religious leaders should help in assisting the children by enrolling them to schools like their fellow counterparts. There is a need for special rehabilitation and trauma centers in the affected states, especially for women and children who have had terrible knowledge during the insurgency period.
\end{abstract}

Keywords: Boko Haram, Children, Insurgency, Negative Impacts, Northern Nigeria, Women.

\section{Introduction}

In Nigeria women institute approximately half of the population; they play an important role as mothers, producers, managers, community developers/organizers. However, they also contribute to the society, socially, politically, and economically, to the development of the nation. It is known that women performed double responsibilities in all the society compared to men by virtue of their dual roles in the industrious and reproductive domains (Makama, 2013).

Northern Nigeria is patriarchal in nature which is a major feature of a traditional society, where men dominate and control everything, by taking care of the wives and children at all cost, or it is a structure of a set of family members with a material base which enables men to control women. Women are therefore subjugated to domestic responsibilities, sometimes they are denied even to obtain proper education, neglected and continually kept at home as house-help(Allanana, 2013; Makama, 2013). With this it is understood that women in the northern region are been taking care of by their husband, it is the responsibility of the husband to provide all the necessary needed goods and services to the family. Considering this major duty of the husband in the family, 
today Boko Haram sect has killed many men in the northern part of the nation and put the lives of women and children in dilemma. Because those in position to cater to the lives of the family members are no longer alive as a result of the Boko Haram sects. Those women that lost their spouse are turned to widows and the children to orphans.

A study by (Shehu Mohammed, 2018), noted that Nigeria and her immediate neighbors (Republics of ChadNiger and Cameroon) have been knockout by the tragedy of Boko Haram insurgents since 2009 claiming thousands of lives and properties worth billions of Naira. It does not end up on the economic problem alone, but it has course a lot of social damages to the life of women and children, in a nutshell, Boko Haram insurgency has made and turned many women into widows and children into orphanages like those of Asia, other African states, and Europe. The activities of the insurgent's sect have extended not only to many towns and villages in the northern region, but also an attempt to break away an essential part of the Nigerian states and transcended to neighboring states of the Republics of Cameroon, Chad and Niger, thereby confusing regional security and the fight against insurgency along the Lake Chad region

In a similar vein (Osaghae \& Suberu, 2005), noted that even before the emergency Boko Haram in Nigeria, Nigeria was characterized with the highest rates of internal ethnoreligious and communal conflict in the world. Right from the year 2009 to present time, Boko Haram insurgency has confounded the North-East states of Nigeria, particularly Adamawa, Borno, and Yobe state, and other parts of the neighboring nations such as Lake the Chad Region - Difa, Niger Republic, far Northern Cameroon and Chad, evacuated millions of people in the above-mentioned places, and turned tens of thousands of women and children to traumatized widows and orphans. In addition to the above a study by (Shehu Mohammed, 2018), unveiled that numerous houses, schools, educational facilities, villages, towns, and markets have been comparatively or completely damaged, destroyed and uninhabited, this has aggravated the levels of poverty and unemployment among the youth in the society. several business organizations were distorted, many prominent and affluent persons were turned into beggars and refugees, most of the central and international businesses in the affected area has crippled. More so, many women were disconnected from their husbands and children, this has directly or indirectly affected the lives of the women and children. In short, it is noted that in Borno State alone, more than 5, 335 classrooms in 512 primaries, 38 secondary schools as well as 2 tertiary institutions were damaged; about 1, 205 public buildings were destroyed. This has affected the educational process of the youth and children leaders of tomorrow.

1.2 Problem Statement

Conflict is not only a threat to government or democracy but to the lives and properties of innocent people in Nigeria; it is also a threat to the women and children in all the society. The negative impact of attacks and reprisals attacks between the Boko Haram sects in northern Nigeria. Has affects the lives of women and children in the northern region. Which has turned the lives of women to widows and children to orphan?. It is known that women are mothers of the next generation and children are the leaders of tomorrow that the society expects to contribute to the nation building. The paper merits to examine the negative impacts of the Boko Haram insurgency on the life of women and children in the northern region.

1.3 Objectives of the Research

This paper examined the negative impacts of Boko Haram insurgency on women and children and exposed the various areas that the insurgent's groups course several damages to women and children in the northern region. The paper also discussed the consequences of the insurgency group on the future generation.

1.4 Research Methodology

This study is qualitative in nature. For the purpose of this article, the researcher used a secondary source of data collection to obtain the important information in line with the topic under study. In this case several books, journal, articles, reports, newspapers, etc. were consulted in extracting the relevant data. That help in developing the article(Braun and Clarke, 2013).

\section{The Emergence of Boko Haram}

Boko Haram is the terrorist group of people formed by some few Islamic sects to fight against western education and the activities related to its operations in the northern region. According to (Walker, 2012) Boko Haram sects Jama'atu Ahlus-Sunnah Lidda'Awati Wal Jihad, known the world over as Boko Haram, is a terrorist Islamic sect in Nigeria that has formed mayhem across the northeastern part of Nigeria and in the federal capital, Abuja. Its fierce bouts on administration offices, the United Nations, mosques and churches loom to disrupt the nation.

Boko Haram appeared in the early 2000s as a small Sunni Islamic sect supporting a firm clarification and execution of Islamic law for Nigerians and Nigeria(Lauren Ploch Blanchard, 2014). Since then Nigeria is experiencing a high flood of insecurity, particularly in the northeastern region by the insurgent group called: The Jama'atu Ahlus-Sunnah lidda Awati Wal-Jihad generally known as Boko Haram.

Giving this,(Musa, 2011), opined that Boko Haram stated their activities since 2001 but was not popular until 2009 when they engaged vigorously in the religious ferocity which happened in the Northeastern region. The name Boko Haram was derived from the Hausa language, in English, it means "Western education is sinful". However, this sect of people rejects everything related to western education and origin, precisely the western 
education; its principles and schemes. "Boko is the Hausa language, in English means western education, while Haram means sinful. It is observed that Boko Haram rejects not only western education but western culture and modern science as well. In a view of (Yusuf, 2009), the belief that the world is a sphere contradict the Islamic principles, as such it should be rejected together with Darwinism and the philosophy that rain comes from water vanished the sun. To him, the group was initiated in 2002 in Maiduguri the state capital of Borno by Ustaz Mohammed Yusuf then. They later relocated to a village in Yobe state called Kanamma in 2004, where they established their base called "Afghanistan". It is from this base they used to organize and attack nearby police outposts, killing police officers, burning Churches and schools with the intention to continue with the attacks in as much as the political and educational system is not changed in line with their philosophies.

3. Literature Review/Conceptualization

According to (Inchi S. I., 1996), Insurgency is a violent organized by an individual or group of individuals to fight or oppose the implementation of law or running of government or react against established authority of the state. In a related development (Ladan M. T., 2012), describe insurgency from three perspectives firstly, to establishes an attack on an unprotected member of the public resulting into wounds or injuries, loss of lives and properties as well as the involuntary internal displacement of persons or group of persons from their living environment. Secondly, to energies of native and external enterprises from the country; and thirdly, it comprise some elements of the traitorous crime, violence, killing, criminalities against humankind.

A study by (Badiora, 2017) observed that insurgency usually has two main features; these include crime and violation of human right in the society. Insurgency is seen as a crime because it is a pattern of internal disorders and stiff nesses that poses serious threats to the society in general and public order for the appropriate authorities, which can ultimately lead to circumstances that loom the life the public and lure the government in power to announce a state of emergency. Just like what happens in Adamawa, Borno, and Yobe State where many people were killed by the Boko Haram group that led to the declared state of emergency by President Goodluck Jonathan on 14 May 2013, because of the negative activities of the radical Boko Haram sect (MNCH2, 2018). However, it is observed that the activities of this sect of individuals have affected the lives of many married women that lost their husbands as a result of the activities of these bad elements, which has turned many women to destitute, widows, and children to orphans, it is noted that the affected children were later dropped from the schools because their fathers were murdered, no one to settle their school fees and other educational responsibilities.

In 2009, the Nigerian government took security actions on this sect as a result of their negative attitude and activities towards people and the society at large because their activities were becoming disturbing and intolerable. As a result of this, their leaders were apprehended alive or arrested and kept them in the police custody, which was later executed extra-judicially. (Ladan M. T., 2012), narrated that Boko Haram was basically against the dishonest western-educated Muslim leaders and government. The group was also capitalizing on popular dissatisfaction with poor governance in Nigeria mostly, in the northern region of the country

A study by (Amadu, 2013), showcase that with the increased in series of attacks and bombing in the Northern region, there is a mass movement and relocation of men and women from the most attacked areas in early 2012 and up to 2015 but with the coming of president Mohammad Buhari into power, things started changing, because he was able to restore peace in those states. With all this the men mostly, businessmen stay behind to continue with their business and to protect their source of income. The sudden relocation of the individual from their town and villages affect the relationship between the husband and wives and directly affects school attendance of their children. Some children forced to join another school in the various town where they relocated to. While those that lost their parents because of the attack were absconded from the school because of financial related problem.

It is noted that since the beginning of 2014, about 1,500 people have been killed in the north-eastern region by the insurgent's group. That made many individuals live in an environment of fear and uncertainty, susceptible to attack from Boko Haram group on the one hand and fronting human rights defilements at the hands of the very state security forces which are supposed to protect them(Amnesty International, 2014).

According to (Lauren Ploch Blanchard, 2014), over 4,000 persons were projected to have been murdered in Boko Haram-related activities, in northern Nigeria making it one of the lethal terrorist groups in the world. However, U.N. and Nigerian officials reported that about 6 million Nigerians have been affected by the violence between Boko Haram sects and the Nigerian government, and more than 300,000 have been disorganized from their town and villages. Looking at this scenario it is observed that most of the people killed are married, some have four, three, two and one wives, only a few of the murdered that are single. All those married have children of under schools age. This negative attitude of the said group has put many women into widow ship and the children to orphans; this will later affect the lives of the women and the children by extension the national economy.

Similarly, (Amnesty International, 2014), reports that since the violence started in 2009, thousands of fighters have also been murdered in clashes between security forces and Boko Haram members across different locations 
in north-eastern Nigeria. And most of those killed are married men who are breadwinners of a family of families, leaving behind two, three or four wives with enormous children. In addition to this thousands of people have died in military custody in Borno and Yobe states, and most of them are married men with children. Many more have been wounded of enforced disappearances and thousands have been endangered to acts of agony and other forms of painful, insensitive and humiliating action in military and police custody in north-eastern Nigeria, many of those affected are family men with many children.

However, it is understood that these terrorist group claimed many lives, so also the armed forces and the civilian joint task force (JTF). In view of this, Amnesty International (2014), reported that from the available information received from eyewitnesses, lawyers, family members, and community activists, nothing less than 622 persons were killed by the security forces on 14 March. And all those killed are family men, these have added to the number of those killed by the insurgent's groups, that turned many women into destitute beggars, widowers and several children to orphans, this will in the near future affect the nation development if necessary measures are not taking towards the children and the women widowers lives. However, it is observed that out of the 622 individuals that were murdered 90\% are married men with many children. All these children were turned to orphans and the wives to widows.

In line with the above revelation, a study by (Shehu Mohammed, 2018), observed that every child born in any situation the parents adds hope and potentiality to the world and fellow humans. What transpires to children at grave dated is likely to have additional effects and impact than things that happen in standard life (Maduewesi, 1999) observed that rightly, about $60 \%$ of Nigerian children face one type of mishandling or the other in this present society. These children want distinct sensitive treatment as parents and children (Santrock, 2003). It is noted that many thousand people have been carried away as detainees and or child-soldiers by Boko Haram revolutionaries making them end up with armed and dehumanized feelings and therefore, only wanting to murder, rape, hurt or harm others.

In a related development a study by (Badiora, 2017), unveiled that the internally displaced persons (IDPs)in Nigeria and other nations are living in an unwarranted situation, but it is understood that in some nation like Nigeria the IDPs encountered many problems with their safety, health, and deprivation of basic social services of lives. It is noted that in the Nigerian IDPs camps, there are several complaints of sexual harassment together with numerous health-related cases or diseases which affects women and children. Besides, there has been a little outbreak of transmittable diseases related to the poor-quality food, safety, safekeeping, water, and sanitation as well as housing.

The activities of the insurgent's group have a negative and at times affected health penalty. This brings an increased absenteeism at the place of work and restricts flexibility, thus dropping the rate of production and incomes. It also leads children to drop out of school when going to school puts them at risk of abuse. Insurgency and state of emergency declared in any state affects women and children of all ages and impacts their full contribution to the national economy. Violence takes many forms, including not only physical, but also sexual, emotional, and economic, as well as pestering experienced in public and in places of work, worship, and education(Paula W. Quentin T., 2018).

\subsection{Widows and Orphans}

Widows and Orphans are sets of people that lost their lives as a result of the Boko Haram activities. In a related development a study by (Shehu Mohammed, 2018), disclosed that Boko Haram insurgency has led to a huge number orphaned children and widows. Is observed that $60 \%$ of all the peoples in the IDPs established because of Boko Haram insurgency are women and children? Similarly, $60 \%$ of all the children in those camps are orphans and such children are encountering a lot of problems which includes but not limited to sociopsychological, medical, economic and ecological trials because of this. (Zastrow, C. H., \& Ashman, 2010), observed that abandoned children suffer from or are victims of physical and mental health care, and educationally deserted, without appropriate and regular life management, they as well face housing dangers, and they lack good household and basic individual and hygiene face social and attachment difficulties, at the same time they lack basic nourishment, meet mental and academic shortfalls and also have expressive and social problems.

Another problem of the insurgent's group epoch is the presence of ignored children all over the affected state's town and villages inclusive and extended to some neighboring areas. Nevertheless, it is understood that many orphans were displaced all over the northeastern region, many of them are abused in one form or the other and in extensive poverty and children and women are poorest in pretentious places.Because of the insurgency. In a report from the (NEMA, 2015), it reported that there are over 5, 000 orphans in the North-Eastern region alone. These children/ orphans if not immediately go to will grow up unschooled, improvised for life challenges, jobless, and crooks as well as counterproductive to the Nigerian state and society(Badiora, 2017).

3.2 Abducted girls in Secondary Schools

A study by (Lauren Ploch Blanchard, 2014), disclosed that in 2013 this group's attacks became more ruthless, gradually aiming students and teachers in various schools in the northern region. He revealed that in July 2013, Boko Haram's leader openly endangered to burn no spiritual institutions and kill their teachers, describing the 
schools as a "plot against Islam." This menace has discouraged thousands of children from attending school in the northern region that already had low turnout rates and literacy levels, especially among women and girls. National statistics unveiled vast differences within Nigeria in the percentage of girls who attend school, with attendance lowest in the northern region.

Yet, in the same year 2013, the insurgent's group came and attacked one girl's secondary school in Chibok and kidnapped over 260 students, after a series of negotiation between the sects and Nigerian government they release most of them and withheld some. Though, this is also not the first time Boko Haram has abducted women in Nigeria. However, those kidnapped were later forced to convert to Islam by the said group and have been used as sex objects by a terrorist group.

In February 2018 over one hundred and ten students (girls) were abducted from one secondary school in Dapchi of Yobe state, still this group of people went into negotiation with the federal government on the release of the abducted girls, at the end the sects agree to released one hundred and nine 109 abducted Dapchi girls out of this one hundred and five safely returned five reported dead as a result of stampede during the abduction, but one girl was not set free because of her religious faith (Dailytrust, $2018 \mathrm{pp} \mathrm{4).} \mathrm{Considering} \mathrm{the} \mathrm{number} \mathrm{of} \mathrm{the}$ abducted girls from the two secondary schools this has affected the lives of many women in the northern region, and it as well as discourages many parents from sending their daughters to schools, and some of them will hardly get someone to marry them because of fear and anxiety, this affects the entire lives of these girls, mother of the next generation. It is known that women are mothers, home keepers, producers, family activist and community organizers(Allanana, 2013; Makama, 2013).

3.3 Future Threats

Considering the negative activities of Boko Haram activities on northern Nigeria the study noted that most of the children that lost their parents are facing a lot of life challenges, such as child abuse raping broken home among others. These affected children are the future youth, if they grew up in this situation it will affect the society at large, this is because most of these will become irresponsible in the society. And if care is not taking these victims of Boko Haram will become a terrorist group in the near future. In addition to this many matured girls and women were been raped by the Boko Haram sect and by extension by some security agents and some agents of the internationaldonors. In relation to child abuse, it is observed that most of the children are drop out from the school because their parents are killed by the insurgents, and no one to take care of them, or to sponsor their education, if these set of people grown up without education and parental care they will become a nuisance in the society.

In a statement made by the acting Managing Director, Nigeria Interbank Settlement System (NIBSS), Mr. Niyi Ajao, during an exclusive interview with TELL, mourned the chaos suicide bombers have done to the Nigerian economy which, he observed has affected the national economy as well as every individual in the nation, and will affect the next generation, if not stopped instantly(Innocent, 2012).

3.4 Psychological Effects of Boko Haram's Attack on Children Education

The activities of the insurgent group are not limited to security agents, but, the students in the various schoolwere been attacked, however, attack on one school or nearby villages put a fear in the mine of students and the people living in the environment, that any schools or villages in the area might be attacked. A study by Ugwumba, E. U. Odom (2015), disclosed that Boko Haram's repeated attacks on several schools across the northeastern region of the nation and this has an insuperable obstacle to education for a large number of children'. He added that the psychosocial impact will definitely affect children's ability to study, and the places where these activities continue may lead to their (pupils/students) withdrawal from school, even if the school remains open, most of the children cannot be allowed to attain school because of the fear of future occurrence.

4. Findings

The paper found that Borno state is the base of the Boko Haram group that is where it started its operations and slowly spread to the northern states like Abuja, Adamawa, Gombe, Kano, and Yobe state, the targeted places include schools, Mosque, Churches, Police Stations Motor parks and public Offices across the northernregion. It was exposed that insurgences have amplified the number of IDPs in the country turning the country into one of the highest IDP populations in Africa. The research disclosed that some IDPs lost their spouse because of the insurgency while some children lost both parents to the insurgency. Findings displayed that some individuals lost their children because of this unwanted activity of the group. It further found that many people were killed by the military men, police, and civilian JTF. And some innocent person died at the police custody because of congestion, hunger, thirsty and some health-related problems,

The study further noted that several women and children have been psychologically traumatized by the negative activities of the Boko Haram and that of the military, police, and civilian JTF and many things they came across during the events time. Therefore, many of them are psychologically affected and they need to be psychologically rehabilitated in order to bring them back to their normal senses and re-integrate them back into their communities. It is observed that many women and children have had their parents and husbands were killed or chopped to death in their presence and their properties and villages set on fire. Boko Haram has evacuated millions of persons from their residence to IDPs camps, including a significant number of children 
and more than $\$ 67 \mathrm{~m}$ is required to acclimatize the displaced and psychologically disturbed individuals in the North Eastern part of the country, especially those children whose condition has worsened as a result of the insurgency. Each and every child needs the necessary social services such as physical, education, and demonstrative backing so as to grow up as a reasonable and responsible adult when grown up in the society, but most of the children problems come up from lack of, poor and rude family, physical and emotional disabilities (see White, S., \& White, 1980).

The study further found that most of the women and girls kidnapped by the insurgent's group in the northeastern part of the country have experienced sexual abuse and rape, suffering and to some extentkilling. A recent a report from Nigeria's Political Violence Research Network unveiled that over $45 \%$ of those murdered by the insurgent's sect are Christian women and children. It is observed that Boko Haram is not the only offender in the women abuse in the northern region. but the government security agents also contributed to the raping and killings of both men and women in the region. an eyewitness reported that women have been randomly arrested by some government security personnel for the simple reason that their family members are alleged associates of the Boko Haram sects. In addition to the above, it is understood that women and girls are also used by the sects at the time of war for labor. Though, their main target is assets as well as the women themselves(see OsitaNjoku, Agnes, and Chikere, 2015).

\section{Recommendations}

- From the available findings, the study recommends that Nigerian government should provide free and compulsory education in the northeastern region especially those children that lost their parents as a result of the Boko Haram insurgents, up to university level.

- The federal and States governments should immediately commence reconstruction of all destroyed schools and provide necessary teaching facilities to the schools to encourage people to continue with their education.

- To encourage the affected children Nigerian government should provide a scholarship to them.

- To avoid future occurrence the government of Nigeria should show higher commitment in mobilizing the armed forces to the northeastern region and provide adequate security in all institutions of learning.

- The government should provide special economic intervention programmes, bail out and fundto the affected states and areas hit by the insurgency.

- There is a need for special rehabilitation and trauma centers in the affected states, especially for women and children who have had terrible knowledge during the insurgency period.

- All trauma visible persons should be given a special mental examination action to avoid and contain possible post-traumatic stress and disorder (PSTD).

- Those children affected by the Boko Haram insurgency should be retrained, re-oriented and put under special care and attention so that they become potentials elements in the future.

- Religion leaders should advise and encourage those with one or two wives to marry more to reduce the number of the windows in the society. And those that are not married should empower to get married to reduce the numbers of the widows roaming on the street.

- Both federal and state government should provide employment opportunities to those affected.

- To overcome future occurrence there is a need for women empowerment to enable them to take care of the orphan's children, or else these children will develop the ideology of retaliation in the near future.

- The federal and state government should call the military men, police, and civilian JTF to order to stop indiscriminate killings in the northern region.

- There is a need to provide adequate security to all targeted places like schools, mosques, churches, 6. Conclusion market police stations among others.

The paper concluded that since the coming of the insurgent sect in the country, it is observed that women and children live have been had shaken. The negative impact of the insurgent group has brought a physical, psychological social and economic harm to Nigeria'ssocial and economic development. Based on the above study, it is the conclusion of this paper that the Boko Haram insurgency in North-Eastern Nigeria has crippled social economic, activities as well as security. Several women have turned to widows, children to orphans, numerous families have become destitute, family ties/bonds broken, many others have become traumatized widows and orphans, many millionaires have been demoted to houseboys, beggars and refugees several enterprises have distorted tens of thousands of lives lost in addition to those eternally disabled and traumatized, abandoned and or uninhibited offspring. Likewise, children born and grownup to mothers in such expressive mayhem are more disposed to difficulties and more likely to grow as adults with psychiatric syndromes. Finally, the activities of the sect have distressing, many communities have become immigrants in their own state; hamlet and homes are demolished by the insurgent's group.

References

Allanana, G. (2013). Patriarchy and Gender Inequality in Nigeria : the Way Forward. European Scientific

Journal, 9(17), 115-144. 
Amadu, S. (2011). School attendance falls in Northern Nigeria, The Guardian, 24th April.

Amnesty International. (2014). Nigeria More Than 1,500 Killed in Armed Conflict in North-Eastern Nigeria in Early 2014.

Badiora, A. I. (2017). Civil Unrest, Insurgences and the Challenges of Community Displacement in SubSaharan Africa: A Silhouette of selected states in Nigeria. International Journal of Criminal Justice Sciences, 12(2), 302-318. https://doi.org/10.5281/zenodo.1034678

Braun and Clarke. (2013). Successful Qualitative Research a Practical Guide for Beginners.

Dailytrust. (2018, March 21). Nigerian newspaper (Dailytrust). News Paper. Nigeria.

Inchi S. I. (1996). The Nigerian Law Dictionary. 1st Edition, Tamaza Publishing Co. Ltd, Zaria, Nigeria.

Innocent, O. (2012). The Cost of Boko Haram Activities in Nigeria. Arabian Journal of Business and Management Review(OMAN Chapter), 2(2), 10-32. https://doi.org/10.12816/0002238

Ladan M. T. (2012). Impact of Insecurity in the North on Internally Displaced People and Migration Flows between Nigeria and Neighbouring Countries. Being a paper presentation made at the forum of European Union Working Group on Migration and Development; Organized by the De.

Lauren Ploch Blanchard. (2014). Nigeria's Boko Haram: Frequently Asked Questions Specialist in African Affairs.

Maduewesi, E. J. (1999). Early childhood education: Theory and practice. Lagos: Macmillan (Nigeria) Publishers Limited.

Makama, G. (2013). "Patriarchy and Gender Inequality in Nigeria: The Way Forward." European Scientific Journal, 9(12).

MNCH2. (2018). Maternal Newborn and Child Health Programme.

Musa, P. (2011). Boko Haram History in Nigeria, Journal of Arts and Social Science, 4(2) 18 -21., 4(2), $18-21$.

NEMA. (2015). National Emergency Management Agency (NEMA) Report, July, Abuja-Nigeria.

Osaghae, E. E., \& Suberu, R. T. (2005). A History of Identities, Violence, and Stability in Nigeria. CRISE Working Paper Series, 1(6), 1-27.

Osita-Njoku, Agnes, and Chikere, P. (2015). Consequences of BokoHaram terrorism on women in northern Nigeria *. APPLIED RESEARCH JOURNAL, 1(3), 101-107.

Paula W. Quentin T. (2018). Women and Girls Global and Regional Trends in Women's LEGAL Protection Against Domestic, (March).

Santrock, J. W. (2003). Children. New York: McGraw-Hill Companies.

Shehu Mohammed, I. (2018). Post Boko Haram Insurgency, Nigeria's National Security, and Emergent Threats. Humanities and Cultures Studies $R \& D, 3(2), 1-15$. Retrieved from https://www.jsrd-humanities.com

Ugwumba, E. U. Odom, T. C. (2015). Boko Haram Insurgency: a Peril to Achievement of Education for all in Nigeria. Education Learning and Development, 3(1), 1-11.

Walker, A. (2012). What Is Boko Haram? United States Institute of Peace, 16. Retrieved from http://www.usip.org/sites/default/files/SR308.pdf

White, S., \& White, B. N. (1980). Childhood: Pathways and discoveries. London: Harper and Row Publishers.

Yusuf, L. (2009). The Principles and Practice of Islamic Religion. Lagos: NOK Publishers Nig. Ltd.

Zastrow, C. H., \& Ashman, K. K. K. (2010). Understanding human behavior and the social environment. Belmont: Brooks/Cole Cengage Learning:

\section{Copyrights}

Copyright for this article is retained by the author(s), with first publication rights granted to the journal.

This is an open-access article distributed under the terms and conditions of the Creative Commons Attribution license (http://creativecommons.org/licenses/by/4.0/) 